\title{
Éghajlatváltozás, és az egyedi szennyvíztisztító berendezés összefüggései
}

\section{Climate Change and the Relationship between the Individual Wastewater Treatment Plan}

Az éghajlat-, és klímaváltozásért számos emberi tevékenység felelös. Ezeknek a tevékenységeknek a légkörre, talajra veszélyes összetevőit többféle módon próbáljuk csökkenteni, annak érdekében, hogy a nem kivánt folyamatot lelassítsuk, megállitsuk. Az egyedi szennyviztisztitók is segítségünkre vannak ebben a „, harcban”, hiszen a szennyvízben jelentősen lecsökken a keletkező metángáz mértéke, szemben a kezeletlennel, megszünteti a nemkívánatos szaghatásokat, és kialakításuk miatt szinte észrevétlenül telepithetök a környezetbe. Célom egy olyan egyedi szennyvíztisztító kisberendezés bemutatása, amely az emberiség számára elérhető, és komolyabb szaktudás nélkül üzemeltethető.

Kulcsszavak: éghajlat, klíma, folyamat, szennyvíz, szennyvíztisztítás, egyedi szennyviztisztitó

Many human activities contribute to climate and climate change. We try to reduce the dangerous components of these activities to the atmosphere and the soil in several ways, in order to slow down and stop the unwanted process. Individual wastewater treatment plants are also helpful in this "fight", as the amount of methane gas produced in wastewater is significantly reduced compared to the treated person, eliminates undesirable odours and can be installed in the environment almost unnoticed.

Keywords: climate, climate process, wastewater, wastewater treatment, individual wastewater treatment

Nemzeti Közszolgálati Egyetem, egyetemi tanársegéd, e-mail: papp.tamas@uni-nke.hu, ORCID: 0000-00015574-8508 


\section{Bevezető}

Napjaink egyik legfontosabb környezeti, társadalmi, gazdasági problémája az éghajlatváltozás. A globális éghajlatváltozás átfogóan veszélyezteti a mai, és még sokkal erősebben a következő generációk életfeltételeit, és a természetet. Az ivóvízkészlet csökkenése, ami a változások egyik következménye, a menekülés és a háborús összecsapások egyik fő oka lehet, hiszen az ivóvíz ritka és drága értékké válik, amelyet inkább a gazdagabbak tudnak megszerezni, ahogy a vihar, az árvíz és az aszály elleni védelmet is ők tudják megoldani. Függetlenül attól, hogy milyen mértékben okozója az emberi magatartás a globális klímaváltozásnak, szükséges az üvegházhatású gázok kibocsátásának csökkentése. Ilyen nemkívánatos gázok közé tartozik a metán is, amely a kezeletlen szennyvízből is a légkörbe kerül. Annak érdekében, hogy minél kevesebb metángáz szabaduljon fel a szennyvízből, kezelésnek, tisztításnak kell alávetni. Az egyedi szennyvíztisztító kisberendezések megoldást nyújtanak olyan területeken is a szennyvíztisztításra, ahol nincsen kiépített csatornahálózat.

\section{Éghajlatváltozás}

Az éghajlati rendszer egy összetett rendszer (1. ábra). Legfontosabb részei a légkör, a hidroszféra, a krioszféra, a szárazföldi felszín, a bioszféra, valamint a közöttük lévő bonyolult kölcsönhatások, amelyeket a külső kényszerek vezérelnek. Külső kényszerek között található például a Nap sugárzásintenzitásának változása, a vulkánkitörések, de az emberi tevékenység is, amely például a légkör összetételének, a felszín különböző tulajdonságainak változtatásán keresztül hat az éghajlati rendszerre. Az éghajlati rendszer úgynevezett nemlineáris rendszer. Ez azt jelenti, hogy a különböző éghajlati kényszerek végeredménye nem az egyedi hatások egyszerű összege vagy különbsége lesz, hanem az éghajlati rendszer állapotának bonyolult, elöre nem biztosan látható változása lesz. Az éghajlati rendszert vezérlő folyamatokat együttes néven éghajlati kényszereknek nevezzük. Mivel az éghajlati rendszert külső hatások szabályozzák, ezért e folyamatokat külső kényszernek is nevezik. A külső kényszerekre az éghajlati rendszer nem vagy csak nagyon lassan hat vissza. Fontos kihangsúlyozni, hogy a Föld-légkör rendszer a kialakulása óta energiaegyensúlyban van, amely azt jelenti, hogy a rendszerbe érkező és az azt elhagyó energia mennyisége megegyezik. A külső éghajlati kényszerek hatására a légkör energiamérlege változik, olyan módon, hogy a „bevételi”, vagy a „kiadási” oldal módosul. Ennek következtében az éghajlati rendszer állapota (az éghajlat) megváltozik. Miközben a Föld-légkör rendszer energiaegyensúlya továbbra is fennmarad, az éghajlati rendszerben egy újabb egyensúlyi állapot jön létre, amely melegebb vagy hidegebb éghajlatot eredményez. ${ }^{2}$ Az éghajlatváltozás negatív hatásai nemcsak a környezetre és az épületekre van hatással, hanem a lakosságra is károsan hatnak. ${ }^{3}$

\footnotetext{
GELENCSÉR-MOLNÁR-IMRE 2012.

KUTI 2019, 413-428.
} 


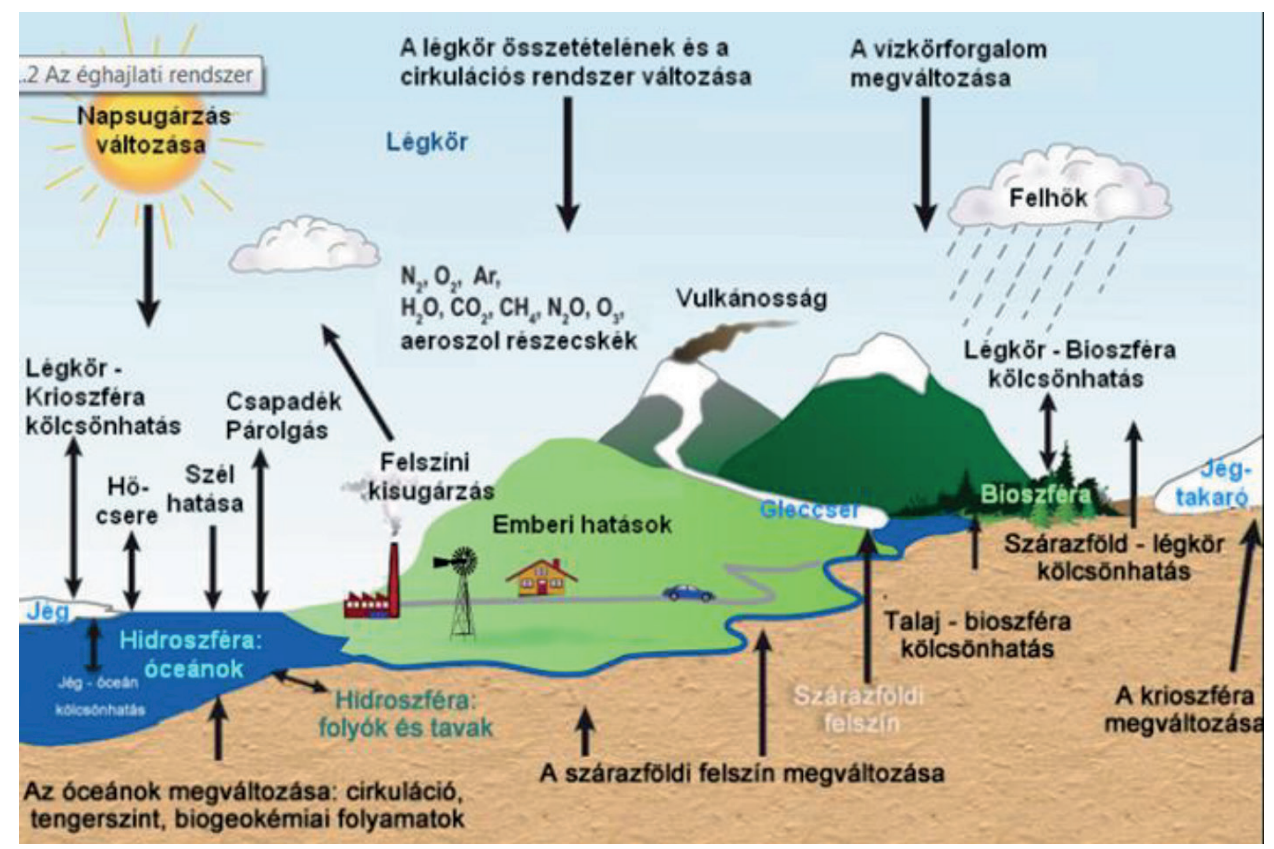

1. ábra. Éghajlati rendszer

Forrás: GELENCSÉR-MOLNÁR-IMRE 2012.

Az éghajlatváltozás három okra vezethető vissza:

- természetes külső tényezők;

- éghajlati rendszer belső ingadozásai;

- antropogén hatások.

\section{Természetes külső tényezök}

Naptevékenység: a Nap sugárzásának időbeli ingadozását, esetleg lassú változásait jelenti, amely a látható sugárzás tartományában évtizedes időskálán 0,1\%-os nagyságrendü. Számos statisztikai vizsgálat mutatott ki a különböző meteorológiai idősorokban olyan periodicitást, amelyek a napsugárzás intenzitásában, illetve a Nap felszínén lejátszódó jelenségekben is megtalálhatók. Nem kevés vizsgálat ugyanakkor e periódusok hiányáról számol be.

A napállandó fluktuációjának idősora: néhány tized Wm-2 értékü, a Nap 11 éves ciklusát megjelenítő ingadozások valamelyest emelkedő trendbe csoportosulnak. Ha e hipotézis igaznak bizonyul, akkor ez részben magyarázza századunk első felének pár tized fokos melegedését, másrészt néhány tized fokos hütő hatást fejthet ki az elkövetkező évtizedekben. 
Vulkánkitörés: egy-egy vulkán kitörése során kén-dioxid és más, föleg szilárd alkotórészek kerülnek a levegöbe, amelynek nyomán 1-3 évre sokszorosára nöhet a sztratoszférikus aeroszolernyő optikai vastagsága. Ehhez hozzájárul a kitörést követő hónapokban a még nagyobb optikai vastagságú vulkáni hamu is. Ez utóbbiak hetek alatt kiülepednek a légkörből, ám a kéndioxid a sztratoszférában kisméretű kénsavcseppekké alakulva néhány évvel a kitörés utánig a sztratoszférában marad. A vulkánkitörések elsődleges hatása a felszínre érkező rövidhullámú sugárzás gyengülésében jelentkezik. A sugárzási hatások eredményeként a felszín közelében csökken, a sztratoszférában viszont emelkedik a hőmérséklet.

\section{Az éghajlati rendszer belső ingadozásai}

A légkör, a szárazföldek, az óceánok, a bioszféra és a szilárd víz, azaz a krioszféra alkotta úgynevezett éghajlati rendszer egyike a tudományos eszközökkel vizsgált legbonyolultabb, nemlineáris rendszereknek. A rendszer fontos méretskálái térben a felhőfizikai folyamatok milliméteres léptékétől az Egyenlítő hosszáig; időben a másodpercnyi élettartamú mikroturbulenciától a sok száz éves óceáni vízkörzésig tartanak. Ebben a rendszerben bizonyos változékonyság minden külső kényszer nélkül is ki tud alakulni. Globális átlagban ez a változékonyság (például az átlag körüli szóródás) néhány tized fokos. Ezt a mértéket egyrészt a tényleges megfigyelések alapján ismerjük, másrészt pedig a globális klímamodellek azon ellenőrző futtatásaiból, amelyek során azokat sem természetes, sem emberi eredetű éghajlat-módosító tényezőkkel nem befolyásolták. Hazánkban is egyre jobban érezhető az éghajlatváltozás, és a hozzá kapcsolódó globális felmelegedés. ${ }^{4}$

\section{Antropogén hatások}

A légköri üvegházhatás antropogén eredetű erősödése miatt a jövő század közepére a Föld hőmérséklete magasabbra emelkedhet, mint a történelem során valaha. Ezért elsősorban olyan, úgynevezett üvegházgázok bizonyítottan emelkedő tendenciája a felelős, mint a szén-dioxid $\left(\mathrm{CO}_{2}\right)$, a metán $\left(\mathrm{CH}_{4}\right)$, a dinitrogén-oxid $\left(\mathrm{N}_{2} \mathrm{O}\right)$ és a halogénezett szénhidrogének.

\section{A metán légkörbe kerülése}

Az emberi tevékenység nyomán az energiaszektor, a mezőgazdaság, a hulladékgazdálkodás és kezeletlen szennyvíz révén jut a legtöbb metán a légkörbe.

4 KUTI-FÖLDI 2012, 60-65. 


\section{Szennyvízkezelés csatornahálózattal nem ellátott területeken}

Az egyedi szennyvíztisztító kisberendezések megoldást biztosítanak a szennyvízkezelésre, olyan területeken, ahol 2000 LE ${ }^{5}$ szennyezőanyag-terhelésnél kisebb, csatornahálózattal nem rendelkező települések területén, üdülőövezetben, autópálya melletti pihenőkben indokolt az egyedi szennyvíztisztító kisberendezés üzemeltetése. Ilyen esetekben a szennyvíz kezelhető helyben. A berendezések létesítéséhez fontos ismerni a beépítésre szánt egyedi szennyvíztisztító kisberendezés minőségi tanúsítványát, ugyanis ma Magyarországon csak olyan kisberendezés hozható forgalomba, és üzemeltethető, amely CE-minősítéssel rendelkezik, amely az MSZ EN 12566-3 szabvány alapján került kiadásra. Amennyiben a terhelés meghaladja a 2000 LE-t, közcsatornára való rákötés szükséges. Amennyiben a terhelés egyenletes, anaerob oldómedencével ellátott egyedi szennyvíztisztító kisberendezés telepítése szükséges, de abban az esetben, ha a terhelés ingadozik, példál üdülöövezetben, akkor a kisberendezés levegőztetése elkerülhetetlen a megfelelő tisztítási hatásfok elérésének érdekében. ${ }^{6}$

\section{Egyedi szennyvíztisztítók}

Sajnálatos, hogy ma még a közhasználatban nem megszokott és keveredik az egyedi szennyvízelhelyezési kislétesítmények, valamint az egyedi kisberendezések szóhasználata, még a szakemberek, illetve, a gyártók, forgalmazók körében is. Fokozott figyelem szükséges, hogy ezt a kétféle - kialakításában, müködésében és nem utolsósorban tisztítási hatékonyságában, valamint árában igen eltérő, de az egyedi, azaz a közcsatorna nélküli szennyvízkezelés fogalomkörébe tartozó - módszert a gyakorlatban is megkülönböztessék.

Egyedi szennyvízelhelyezési kislétesítmény: olyan létesítmény, amely a környezeti elemek terhelését csökkentve a települési szennyvizek nem közműves elvezetésére, tisztítására és elhelyezésére szolgál, a közműves szennyvízelvezetéssel és -tisztítással egyenértékü környezetvédelmet és életminőséget biztosít. Az egyedi szennyvízelhelyezési kislétesítmény a szennyezőanyagok lebontását energiabevitel nélkül végzik. Technológiai elemei: az oldómedence, a kavics- és homokszűrő(k), amelyek összességében lehetővé teszik - a földtani közegbe történő végső kibocsátás esetén - a növényzet és a talaj élővilága számára a tisztított szennyvizek maradék tápanyagtartalmának hasznosítását, vagy a felszíni vizekben történő ártalommentes elhelyezést. Az egyedi szennyvíztisztító kisberendezés olyan létesítmény, amely a települési szennyvizek nem közműves elvezetésére, tisztítására és elhelyezésére szolgál, a közműves szennyvízelvezetéssel és -tisztítással egyenértékű környezetvédelmi megoldást biztosít. A szennyező anyagok lebontását energiabevitel segítségével végző egyedi szennyvíztisztító kisberendezésnek biztosítania kell, a szennyvizek szennyezőanyag-tartalmának külön jogszabályban előírt mértékủ eltávolítását, akár felszíni víz, akár a földtani közeg a befogadó.

\footnotetext{
5 LE: A szennyvíz szervesanyagtartalmának mértékegysége, amely egyenlő azzal a szervesanyag-mennyiséggel, amelynek lebontásához 60 grammos (BOI5) oxigénigény társul.

6 Gelencsér-Molnár-IMRE 2012.
} 


\section{Egyedi szennyvíztisztító kisberendezések kivitelezése}

Manapság számos cég foglalkozik egyedi szennyvíztisztító kisberendezések tervezésével, gyártásával, kivitelezésével, telepítésével, beüzemelésével. A gyártók háromféle típusba sorolják be a saját terméküket a berendezés kapacitására vonatkozóan: kicsi, közepes és nagy. Ezek a besorolások cégenként eltérnek egymástól, mert különböző lakosegyenértékeknél húzzák meg a határt, szem előtt tartva a felhasználási területeket. Minden gyártó kiköti, hogy milyen szennyeződések nem kerülhetnek a kisberendezésbe, amelyek rontják a tisztítás hatásfokát, dugulást és egyéb károkat okozhatnak.

\section{Öko Tech Home által gyártott, és forgalmazott egyedi szennyvíztisztító kisberendezés bemutatása}

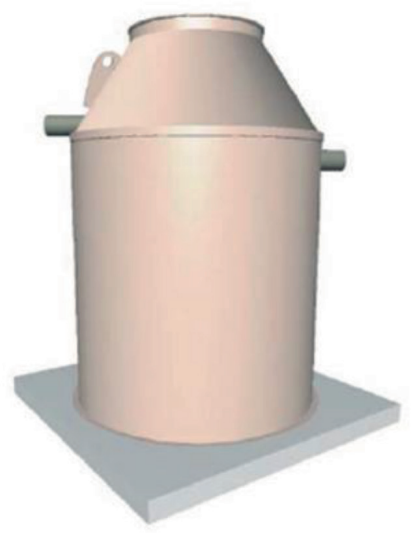

2. ábra. A.B.Clear biológiai szennyvíztisztító berendezés

Forrás: https://vtk.uni-nke.hu/document/vtk-uni-nke-hu/Schuszter\%20P\%C3\%A9ter.pdf (A letöltés dátuma: 2019. 04. 06.)

Az Öko Tech Home Kft. 2004 óta foglalkozik biológiai szennyvíztisztító berendezésekkel és azok kiegészítőivel. Úttörő szerepet vállal a kistisztítók magyarországi megismertetésében, elterjesztésében. A szennyvíztisztító berendezések telepítését, üzembe helyezését is minden esetben elvégezik, így ezen a területen jelentős tapasztalatot halmoztak fel az évek során. Többéves gyakorlati tapasztalat után megkezdték a saját fejlesztésű biológiai szennyvíztisztító termékcsalád megalkotását. A letelepített szennyvíztisztító berendezések müködési és karbantartási tapasztalatait felhasználva olyan berendezést fejlesztettek, amely magas tisztítási hatásfok mellett minimális karbantartási igénnyel üzemel. Törekedtek arra, hogy a meghibásodási lehetőség minimális legyen, a szennyvíztisztító berendezés kopó alkatrészeket nem tartalmaz. Termékük emellett rendelkezik CE megfelelőségi tanúsítvánnyal is. Fontos, hogy az egyedi biológiai szennyvíztisztító berendezés használata következtében tudatosabban választjuk meg 
a háztartási tisztító és egyéb vegyszereket. Azon felhasználóink is, akik korábban nem a környezetbarát tisztítószereket részesítették előnyben, áttérnek az ilyen, lebomló tisztítószerek használatára. Ezáltal egyszerre segítjük elő az energiatakarékosság és a környezetvédelem ügyét.

\section{A.B.Clear kisberendezések bemutatása}

Az alábbi adatok a VITUKI (Vízügyi Tudományos Kutatóintézet) által készített jegyzőkönyvből származnak. Ezek alapján az A.B.Clear biológiai szennyvíztisztítók megfelelnek a 28/2004. (XII. 25.) KvVM rendelet 2. számú melléklete 3. területi kategóriájának, amely az időszakos vízfolyás befogadóra vonatkozik.

1. táblázat. A.B.Clear 6, 8 és 10-es típusú szennyvíztisztító kisberendezés technikai adatai

\begin{tabular}{|c|c|c|c|}
\hline Technikai adatok & A.B.Clear 6 & A.B.Clear 8 & A.B.Clear 10 \\
\hline Napi kapacitás $\left(\mathrm{m}^{3}\right)$ & 0,78 & 1 & 1,3 \\
\hline Átmérő (mm) & 1330 & 1330 & 1500 \\
\hline Magasság (mm) & 1900 & 2200 & 2530 \\
\hline Befolyócső magassága (mm) & 1380 & 1680 & 1715 \\
\hline Kifolyócső magassága (mm) & 1220 & 1520 & 1555 \\
\hline Befolyócső és kifolyócső átmérője (mm) & $110 / 110$ & $110 / 110$ & $110 / 110$ \\
\hline Légbefúvó nyomása ( $\Delta$ pmbar) & 230 & 230 & 230 \\
\hline Légbefúvó levegőszállítási kapacitása (l/perc) & 30 & 37 & 52 \\
\hline Mikrobuborékos levegőztető elem ( $\varnothing 63 \mathrm{~mm}$ ) hossza (mm) & 0,3 & 0,36 & 0,5 \\
\hline Légbefúvó áramfogyasztása (W) & 60 & 60 & 80 \\
\hline
\end{tabular}

Forrás: http://okotechhome.hu/muszaki/ (A letöltés dátuma: 2019. 04. 06.)

\section{Gyártó által ajánlott felhasználási területek}

Családi házak: Családi házak esetében lehet a legegyszerübben megvalósítani az önellátó biológiai szennyvíztisztítást. A víz újrahasznosítását is egyszerűen és olcsón ki lehet építeni, a tisztított vízzel öntözhetjük a kertet! Amennyiben WC öblítésre is felhasználjuk a tisztított vizet, az ivóvíz-felhasználás 30-40\%-kal is csökkenhet. A berendezés a terhelésingadozásokat tág határok között türi, így sem a néhány napos, hetes nyaralások, sem a nagyobb „vendégjárások" nem jelentenek gondot, ezek áthidalhatók egy mikroprocesszoros vezérlőegység közbeiktatásával. A berendezések minimális helyigénye, és az olyan kiegészítők, mint a müfüvel bevont fedelek szinte láthatatlanná teszik a berendezéseket bármelyik kertben.

Nyaralók, hétvégi- és vadászházak: Ezen ingatlanok esetén a terhelés ingadozása sok esetben jelentős. Sokan télen egyáltalán nem, tavasztól őszig viszont szinte folyamatosan, életvitel-szerủen használják a nyaralót. Ebben az esetben is ajánlott a kisebb, néhány napos, hetes ingado- 
zások áthidalására a mikroprocesszoros vezérlőegység, viszont a több hónapos, téli leállásnál már más megoldás szükséges. Ilyenkor a szennyvíztisztítót téliesíteni kell, ki kell szivattyúzni, majd fel kell tölteni tiszta vízzel. Az újbóli használatbavételkor újra kell indítani a berendezést.

Panziók, motelek: A biológiai szennyvíztisztítás a vendéglátásban is jó befektetés, akár a szennyvízelvezetés kiváltását, akár az újrahasznosításból eredő megtakarítást nézzük. Jellegükből adódóan ezen létesítményeknél is erős terhelésingadozások lehetnek, sok létesítménynél szezonális a vendégforgalom. Ilyen esetekben megoldást jelent két kisebb szennyvíztisztító telepítése. Így alacsony terhelésű időszakban csak az egyik berendezés üzemel, nagyobb terhelés esetén pedig a másik berendezés is beindítható, tehát a rendszer kapacitása tág határok között változtatható. Ezenfelül azon panziók, motelek számára is javasolható az egyedi biológiai szennyvíztisztítás, akik az ökoturizmushoz méltó helyeket szeretnének biztosítani vendégeiknek.

Társasházak: A családi házakhoz hasonlóan társasházak esetében is alkalmazhatók biológiai szennyvíztisztító berendezések, ráadásul ebben az esetben még a terhelésingadozások sem számítanak olyan mértékben.

Üzemek, irodák, munkahelyek: E létesítmények esetén is bevált módszer a biológiai szennyvíztisztítás, a víz ugyanúgy újrahasznosítható WC-öblítésre, valamint az üzem körüli terület öntözésére stb. Fontos azonban megjegyezni, hogy a berendezések kommunális szennyvíz tisztítására alkalmasak, így ha bármilyen egyéb, ipari, technológiai szennyvíz ártalmatlanítása is szóba kerül, szükséges egyeztetni a lehetséges előtisztítási és egyéb megoldások kapcsán.

Tanyák: A központi szennyvízcsatorna-hálózatoktól távol eső tanyák esetében jelenleg elterjedt emésztőgödrök, és egyéb, nem igazán környezetbarát megoldások helyett tiszta, olcsó megoldást jelent a biológiai szennyvíztisztítás. A tisztított víz itt is hasznosulhat, például öntözővízként. A berendezés áramszükséglete minimális, így az könnyedén megoldható napelemes, szélkerekes, vagy egyéb alternatív rendszerekről is.

\section{Mi történik a vízzel?}

Biológiai szennyvíztisztító berendezéseink segítségével a kommunális szennyvíz a megtisztítás után helyben többféle célra újrahasznosítható. Legcélszerübb mód a növények gyökérzónás öntözése. További vízkezelés esetén WC-öblítésre vagy autómosásra is használható a biológiailag tisztított víz. Például egy négyfős háztartásban a WC-öblítés a vízszámla 35-40\%-át teszi ki. Ez megtakarítható a tisztított víz felhasználásával. Ahol meglévő betonemésztőt választanak ki, ott az a biológiai szennyvíztisztító beüzemelését követően felhasználható a megtisztított víz tárolójaként, és így könnyebben lehet a tisztított vízzel gazdálkodni. Amennyiben a víz nem kerül újra felhasználásra, úgy sóderágyban elszivárogtatható, vagy vízjogi engedély esetén élővízbe engedhető. Az elszivárogtatás, vagy más néven szikkasztás, az esővíz vagy a biológiailag megtisztított szennyvíz újbóli felhasználásának egyik legegyszerübb módja. A víz egy föld alatti csőrendszeren keresztül szivárog el a talajba. Az elszivárogtató rendszer egyrészt jelentheti a túlfolyót is a vízgyűjtő tartálynál, másrészt így biztosítható a kerti növények gyökérzónás öntözése. A szikkasztó rendszer legfőbb része egy legalább 10 méter hosszú dréncső (kilyuggatott PVC-cső), amelynek egyik vége az esővízgyűjtő tartály kivezetőcsövéhez csatlakozik, és a talajban vezetve, kis lejtéssel tovább haladva, a rendszer végénél a talaj fölé egy függő- 
leges csővel kivezetve végződik. A jobb szivárgás érdekében a cső köré nagyméretű, mosott (kulé)kavicsot kell beásni. Az elszivárogtató cső alá ajánlott $40 \mathrm{~cm}$ szélesen $60 \mathrm{~cm}$ vastagságú kuléágyat készíteni. Az elszivárogtató árkát a kulékavics és a dréncső fölött geotextíliával kell befedni az elsárosodás elkerülése végett. Ezt követően a maradék az eredetileg kitermelt talajjal visszatemethető, így gyalogosan vagy jármủvel járható felületet kapunk. A tartályba az esővíz a fagyhatár alatt érkezik meg. Ez a befolyó. A túlfolyónak a befolyó alatt kell lennie, legalább $2 \mathrm{~cm}$-rel. Az elszivárogtató cső így végig a fagyhatár alatt megy. Minimális lejtése a csatornacsövekének megfelelő, azaz méterenként fél centiméter. Az elszivárogtató cső fektetéséhez szükséges árkot célszerű markolóval kiásni, hogy egyenletes legyen, mivel az aljának teljesen vízszintesnek kell lennie. A szikkasztórendszert csak olyan talajon lehet kiépíteni, ami addig nem volt megbolygatva, vagy az évek során megfelelő mértékben visszatömörödött.

\section{Mi történik a keletkezett iszappal?}

E szennyvíztisztítók egyedülálló technológiát alkalmaznak a keletkező iszap kezelésére. Az újítás lényege egy olyan szerkezet, amely a keletkező fölösleges iszapot vízteleníti, és könnyen kezelhető formában, a tartályon belül egy zsákban gyűjti. Ezzel a fölös iszap szippantása elhanyagolhatóvá válik, az összegyüjtött iszap pedig akár a felhasználó által, otthoni körülmények között is komposztálható, és növényi tápanyagként hasznosítható. A technológia másik elönye, hogy a tartályban lévő iszap mennyiségét automatikusan szinten tartja, így az iszapzsák rendszeres ürítése esetén sem a szennyvíztisztító túlzott eliszaposodása, sem a túl alacsony iszapszint nem lehetséges.

\section{Szennyvíztisztítás és esővíz-hasznosítás}

A szennyvíztisztítás és az esővíz hasznosítása egyetlen rendszerben is megoldható. Ilyenkor ideális esetben a gyűjtött esővíz és a tisztított víz egy ciszternában gyűlik, majd egy szivattyú segítségével hasznosítható. A fölösleges vízmennyiség egy elszivárogtató rendszeren, vagy más túlfolyón keresztül távozik a rendszerből. Egy ilyen összetettebb megoldással jelentős vízmegtakarítás is elérhető, lévén, hogy ha a vizet kizárólag WC-öblítésre hasznosítják, máris 30-40\%-kal csökken az ivóvíz felhasználása, sokoldalúbb felhasználás (például öntözés, autómosás) esetén ez a szám akár 50-60\%-ra is emelkedhet.

\section{A.B.Clear szennyvíztisztító kisberendezés müködési elve}

A biológiai szennyvíztisztító berendezésben alkalmazott technológia az eleveniszapos biológiai tisztításon alapszik. Az épületen kívül telepített szennyvíztisztító berendezésben az épületben keletkező szennyvizek (konyhai, fürdőszobai) beérkezését követően a vízben lévő szennyező anyagok eleveniszap segítségével anaerob és aerob biológiai folyamatok során lebomlanak. A berendezések az úgynevezett teljes oxidációs eleveniszapos szennyvíztisztítás elvén működnek, hasonlóan, mint a nagy, városi szennyvíztisztító telepek. Az összes munkafolyamat 
egy tartályon belül zajlik, a különálló kamrák más és más szennyvíztisztítási fázisnak felelnek meg. A bontást mikroorganizmusok végzik el. Minden munkafolyamatot, ahol ez szükséges, egy elektromos levegőszivattyú lát el levegővel. A szennyvíz az első, anaerob kamrába jutva egy kosárszürőre kerül, amely felfogja a nagyobb szilárd szennyeződéseket. A vízben oldódó anyagok itt a vízmozgatás miatt felaprózódnak, és a szennyvízzel együtt a szürőn, majd a kamrán átjutva az anoxikus térbe kerülnek. Itt zajlik a szennyeződések levegő nélküli bontása. Ezt követően a folyadék az aerob, azaz mesterségesen levegőztetett térbe kerül. Itt egy mikrobuborékos levegőztető cső látja el a baktériumokat oxigénnel, ezeknek a folyamatoknak köszönhető, hogy a berendezés működése nem jár kellemetlen szaghatással. Ez az utolsó lebontási folyamat, amely után a szennyvíz az utóülepítő térbe jut. Itt a tiszta víz és az iszappá összeállt, megmaradt szennyeződések szétválnak, előbbi a felszínen marad, míg az iszap a kamra aljára lerakódik. A környezetvédelmi előírásoknak és határértékeknek megfelelő, tiszta víz a kifolyócsövön keresztül távozik a berendezésből. A berendezésben lévő mamutszivattyúk feladata a termelődő iszap tartályon belüli keringtetése, valamint a fölösleges iszap kiemelése az iszapvíztelenítő egységbe, ahol könnyen kezelhető formában, víztelenítve tárolódik kiürítéséig. A tisztított víz közvetlenül végső elhelyezésre is kerülhet (például elszivárogtatás), vagy egy ciszternában tárolható a későbbi újrahasznosítás érdekében. Az A.B.Clear berendezésekben az összes munkafolyamatot levegő működteti, amelyet a levegőszivattyú szolgáltat. Más mozgó alkatrész nincsen a szennyvíztisztítókban.

Az elektromos részegységek az alábbiak: membrános levegőszivattyú (gyári tartozék); kis teljesítményű, csendes, 230 V-os hálózati áramról üzemelő készülék. Alapfelszereléssel folyamatosan üzemel és negyedévenként tisztítani kell a levegőszürőjét, 50 ezer üzemóránként cserélendő benne a membrán.

Váltómotor (gyári tartozék): a levegőszivattyúból ezen készüléken keresztül alapesetben a szennyvíztisztítóba jut a levegő, de az előre beállított időpontokban (gyári beállítás szerint hetente egyszer) az iszapzsák mamutszivattyújába irányítja az összes levegőt, ekkor történik a fölösleges iszapmennyiség eltávolítása és víztelenítése.

Mikroprocesszoros vezérlőegység (választható kiegészitő): abban az esetben javasolt, ha a szennyvíztisztítót a tervezettnél lényegesen kevesebben használják, vagy gyakran ingadozik annak terhelése. Háromállású időkapcsolóként üzemel, az üzemmódokat a felhasználónak kell igény szerint beállítania. 


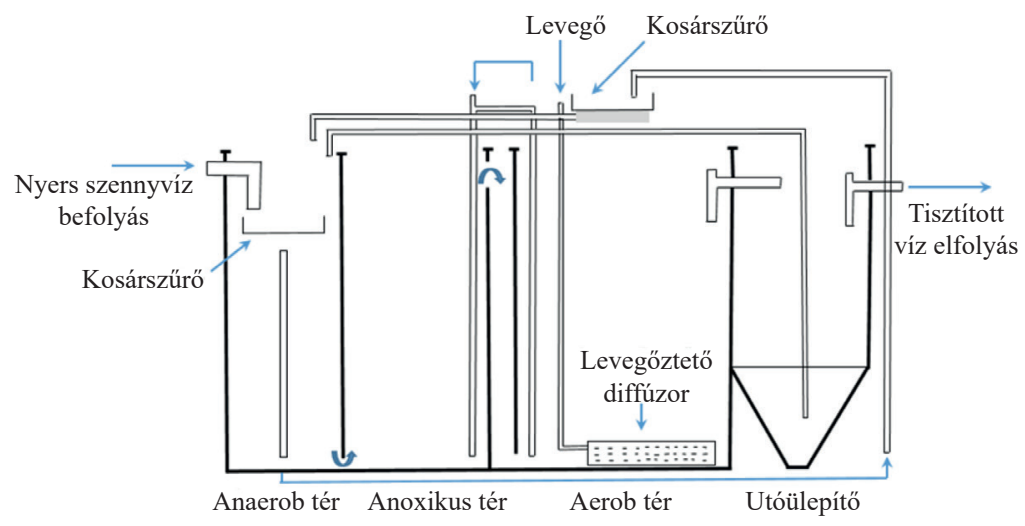

3. ábra. A.B.Clear egyedi biológiai szennyvíztisztító müködési elve

Forrás: a szerző szerkesztése

\section{Összegzés}

A környezetszennyezés, klímaváltozás mérséklésére az emberi társadalom számos területen próbál megoldásokat találni. Ezt bizonyítja a bemutatott egyedi szennyvíztisztító kisberendezés is, amely csak egy a sok közül, amelyet Magyarországon gyártanak, és forgalmaznak. Minden gyártó terméke megfelel a mai követelményeknek, CE-minősítéssel rendelkezik, és a kibocsátott tisztított szennyvíz paraméterei is megfelelnek az érvényben lévő szabványoknak. A berendezések segítségével számos területen lehetőséget biztosítanak a helyben történő szennyvízkezelésnek. Amennyiben csatornahálózattal nem rendelkező területeken alkalmazzák ezeket a berendezéseket, még ha kis mértékben is, de hozzájárulnak az éghajlatváltozás lelassításához, hiszen így csökken a környezetterhelés.

\section{Felhasznált irodalom}

GelENCSÉR András - MOLNÁR Ágnes - IMRE Kornélia (2012): Az éghajlatváltozás okai és következményei. Pannon Egyetem. Elérhető: http://mkweb.uni-pannon.hu/tudastar/ff/02-eghajlat/Eghajlat. xhtml\#d6e55 (A letöltés dátuma: 2019. 04. 06.)

KUTI Rajmund (2019): A globális felmelegedés hatására kialakuló szélsőséges időjárási jelenségek megjelenési formái és következményei Magyarországon. In FöLDI László - HEGEDűs Hajnalka szerk.: Adaptációs lehetőségek az éghajlatváltozás következményeihez a közszolgálat területén. Budapest, Nemzeti Közszolgálati Egyetem. 413-428. Elérhető: https://ludita.uni-nke.hu/repozitorium/ bitstream/handle/11410/11183/adaptacios_lehetosegek_az_eghajlatvaltozas_kovetkezmenyeihez_a_kozszolgalat_teruleten.pdf? sequence=1\&isAllowed=y (A letöltés dátuma: 2019. 04. 06.)

KUTı Rajmund - FöLDı László (2012) Extreme weather phenomena, improvement of preparedness. Hadmérnök, 7. évf. 3. sz. 60-65. Elérhetö: http://hadmernok.hu/2012_3_kuti_foldi.pdf (A letöltés dátuma: 2019. 04. 06.) 


\section{Internetes források}

Biológiai szennyvíztisztítás. ÖkoTechHome - Műszaki adatok. Elérhető: http://okotechhome.hu/ (A letöltés dátuma: 2019. 04. 06.)

Egyedi szennyvíztisztítás - Gyakorlati tapasztalatok (2019). Decentralizált Szennyvíztisztítás Konferencia. NKE Víztudományi Kar. Elérhető: https://vtk.uni-nke.hu/document/vtk-uni-nke-hu/Schuszter\%20 P\%C3\%A9ter.pdf (A letöltés dátuma: 2019. 04. 06.)

\section{Jogforrás}

28/2004. (XII. 25.) KvVM rendelet 